\title{
Om vår egen benektelse av selvmordet: noen behandlingserfaringer
}

\author{
Ved Petter Lohne
}

\section{Mennesker som lever med et intenst rusmisbruk, er sjelden i sentrum av sine egne liv. Nåtiden er knapt til stede for dem, utover i jaget etter rus. Lengsel til en fortid der drømmene fantes eller til en fremtid uten angst og smerte, blir ofte tema i våre daglige møter med dem.}

Det kan kjennes som det nåtidige handler om "de andre", om dem som følger klokken mellom offentlige og private avtaler. D et sårbare ligger like un der maskene av raseri, likegyldighet og distanse. A llerede i de første berøringspunktene, når vi møtes ansikt til ansikt, kanskje uten øyekontakt og i ørsmå glimt, beveges vi av bølger av sjenanse, frykt for nye skuffelser, nye avvisninger, eller av uklare fornemmelser av skam. Det nåtidige innhenter oss begge, behandler som pasient, allerede fra de første spede begynnelser på relasjonsdannelse.

$\AA$ møte sinnslidende rusavhengige er å fylle sin dag med slike erfaringer. En forståelse med utgangspunkt i det Vetlesen og Stänicke i boken "Fra H ermeneutikk til psykoanalyse" (O slo 2000) kaller "tilværelsens eksistensielle grunnvilkår", synes vi gir grunnlag for å reflektere rundt disse erfaringene. Vi finner mening $i$ følgende formuleringer:

- Våre relasjoner til hverandre kjennetegnes av sårbarhet.

- Vi er alle dypt avhengige av hverandre.

- Døden er uomgjengelig, og vi vil alle møte den.

- I én forstand er vi alle alene med vårt ansvar og våre valg.

- A nsvaret for «den andre» er grunnleggende for det å være menneske.

Prosjekt R us og Psykisk Lidelse er opprettet for å komme dem i møte som blir ståen de utenfor, de som har gjort flere alvorlige forsøk på endring sammen med ordinære tiltak, de som ofte opplever seg som kasteballer mellom rusomsorg og psykisk helsevern. Vi er et femårig prosjekt med åtte kliniske medarbeidere, som med en begrenset pasientmengde i 2 år skal kunne arbeide intensivt med flere kontakter pr. uke og pågående engasjement i pasientens miljø. Et flertall av våre pasienter har en psykotisk grunnlidelse, ved siden av rusbruk, som på ulike måter virker sammen med denne. $\mathrm{H}$ os andre er angsten og den vonde og uforl øste sorgen det mest smertefulle.
Vi er bedt om å forholde oss til de utsøøtte. Vi forsøker å skape kontakt der hvor samfunnet har lidd nederlag, der hvor toleransen, respekten for anderledeshet og likeverd, ikke har holdt mål. I det jødiske samfunnet fantes tidligere syndebukkritualet. M enneskenes urene og onde tanker og følelser ble konkret gitt til en geitebukk ved at man berørte den. Deretter ble den utstøtt, den ble jaget bort fra hjemmet, for å dø alene. Vi vet at offerritualene, der mennesker eller senere dyr ble ofret, også hadde slike symbolske betydninger. Det hender at slike perspektiver slår innover oss når vi konfronteres med overveldende motkrefter, som ustanselig bygger barrierer mot anderledesmennesker. V i vet at dødeligheten hos våre pasienter er stor. Fortellingene som når oss er ladet med død, med rusbruk som sjan sespill, om fysisk og psykisk smerte som fjerner dødsangsten for en tid, om tap av utallige venner og familiemedlemmer. $0 \mathrm{~g}$ utsagnene om at håpet ikke er der, at livet ikke kan leves, og at døden er eneste utvei.

I behandlingsfeltet er det en kjent sak at faren for selvmord kan være stor henimot utgangen av alvorlig depresjon, når kreftene og mere rasjonell bevissthet vender tilbake. I rusfeltet fokuseres det oftest på at man er spesielt i fare for å dø av overdose når man har vært abstinent en tid, og ikke justerer mengden en bruker. Kanskje er det slik at denne fokuseringen på overdosene og på stoffet i seg selv, er en måte å unngå det ansvaret vi som blir tilbake sitter med? Jeg vil argumentere for at her ligger det en del av en smertefull sannhet.

M ennesker som ikke fikk utvikle grunnleggende tillit i sitt miljø da de kom til verden, eller der forutsetningene verken hos det selv eller i miljøet rundt lå til rette for gjensidig vekst, bærer etter vår erfaring med seg dyp følelse av skam og mindreverd. Det alvorlige er at nærhet til andre og oppriktig omtanke fra mennesker de kommer i berøring med, så ofte medfører nesten dødelig smerte. Den tidlige smerten vekkes igjen. Dermed må relasjonen angripes. Enten ved tilbaketrekning, eller ved angrep på den andre, eller der smerten allerede er altfor stor, ved angrep på eget liv og egen helse.
A li er 21 år, heroinist og bor sammen med sine foreldre. $\mathrm{H}$ an har hatt en psykotisk lidelse i tre år, som forverres kraftig ved heroinbruk. E tter fem ukers forsvarlig avru sning flytter han hjem, og mens han venter på behandling ved rusinstitusjon skjer følgende: $\mathrm{H}$ an "sprekker" på stesolid, og far finner ham på balkongen i 5. etasje klar til å hoppe. $\mathrm{H}$ an er fortvilet og sikker på at han aldri vil kunne slutte med stoffer. For behandler blir oppgaven i samtale med gutten og foreldre å forsøke å gjenreise håpet. Veien synes endeløs: en stadig kamp på liv og død der pasientens heroinbruk og selvmordstrusler angriper relasjonen mellom pasienten og foreldrene og behandlerens forsøk på å etablere kontakt over tid.

De al vorligste spørsmålene synes vi melder seg når behandlingsforløpene går mot slutten. Behandlingskulturen fører med seg en tenkning om en lidel se som skal helbredes, og at dette skal skje innen et visst tidsrom. Selv om deltakerne i relasjonen slett ikke opplever det naturlig, legger systemforhold opp til at vi skal trappe ned og avslutte relasjonen mellom pasient og behandler. $\mathrm{N}$ ye mennesker står også for tur og venter på behandling. O g selv om avslutningstidspunktet er helt åpent, vil ofte pasienten ha med seg idéen om at man ikke kan fortsette i behandling i all evighet.

Vår erfaring er at behandlerne ofte går rundt grøten når behandlingsforløpet går mot slutten. Vi ønsker jo sá gierne at alt skal gå bra, og vi vil jo ikke slå beina under et spirende selvstendiggjøringsprosjekt. D et ser ut til å være knyttet intense erfaringer av skam og æresfølelse til det à avslutte. Det kan oppleves nedverdigende å måtte ringe opp igjen og be om hjelp når det kniper. $\mathrm{Og}$ har man tidlig i livet erfart vanskelige kontaktbrudd, som en selv har tatt det følelsesmessige ansvaret for, tror man lett at man vil bli avvist, at en behandler med følelse av mislykkethet vil gå hjem den dagen, og så videre. Dette å ønske å skåne våre nærmeste for skuffelser ligger nær for oss alle. Tanker omkring død hører hjemme i all atskillel se. Direkte tale omkring dette grunnvilkår i tilværelsen hører derfor hjemme i avslutningsarbeidet. 
En 35 år gammel tidligere heroinist med manisk-depressiv sinnslidelse, som vi møtte 2-3 ganger pr. uke i to år, festet seg ved en nekrolog over en kvinne som hadde sin sterkt handikappede sønn boende hos seg til hun døde. $H$ ans sterke følelser rundt dette vedvarte i flere uker, før han en dag kunne si at han ville kunne komme på denne måten til oss bestandig. Etter å ha grått en stund sa han: "D e ordene satt langt inne!" D et viste seg å være helt avgjørende for avslutningen at han kunne stikke innom for å forsikre seg om at vi fremdeles fantes i verden.

Per var 38 år og heroinmisbruker i 20 av disse. $\mathrm{H}$ ans psykiske lidelse var sammensatt av tung depresjon, antisosialitet og A DH D gjennom barndom og ungdomstid. $G$ jennom behandlingstiden ved et terapeutisk samfunn ble det også klart at Per manglet evnen til å mestre vanskelige daglige situasjoner. F. eks kunne han på refleks sette foten i dørsprekken når postkontoret stengte rett foran ham, med derav føl gende oppstuss, securitasvakter m. m. M ed tett oppfølging flere ganger pr. uke lyktes det ham å finne stabilitet $i$ tilværelsen. Familien lovpriste behandlingen. $M$ en så inntraff det uheldige. Per ble forelsket og fikk seg bolig og arbeid $\mathrm{i}$ en annen by. $\mathrm{H}$ ans problem med ikke å klare å komme opp om morgenen, som kameratene hjalp ham med før, tok overhånd. $H$ ans nærmeste behandlere så ham så sjelden som hver 14. dag. E tter 2-3 måneder ble han funnet død av en overdose heroin, hjemme. $\mathrm{H}$ an hadde da mistet jobben, og vi tror at såret stolthet eller ærekjærhet hindret ham fra å fortelle det til folk rundt seg. Vi spurte oss etterpå: H vorfor reiste vi ikke de 3-4 timene to ganger pr uke for å fortsette tett oppfølging? D et hadde tatt mye tid, blitt dyrt osv. M en likefullt, når vi ser tilbake, ante vi ikke at noe slikt kunne komme til å skje? $\mathrm{H}$ adde vi ikke allerede nok erfaringer med vanskelige behandlingsavslutninger, med hvordan forventningene skrus opp når det går bra, med såret stolthet og derav kanskje planlagte overdoser med dødelig utgang? V $\mathrm{i}$ kan dessverre fortelle mange slike historier.

K jell, 36 år, heroinmisbruker og i perioder paranoid psykotisk, fikk fast arbeid med psykisk utviklingshemmede. $E$ tter to års frihet fra heroin opplevde han «nesten i transe» å bli styrt mot "plata". H an brukte det en gang og sa noen uker senere til sin behandler at det skulle bli med det, og at han nå helt og fullt ville gå inn i A nonyme $\mathrm{N}$ arkomane, og også slutteå drikke. D en ettermiddagen hadde behandleren en ubehagelig følelse. $\mathrm{H}$ adde han for lettvint godtatt K jells planer? I dagene etter møtte ikke K jell på jobb. En venn fant ham. D et opplevdes som om han hadde giennomført et ensomt avskjedsrituale: overdose heroin i badekaret, med stearinlys tent i badets fire hjørner.

Kunne Kjells selvmord latt seg forhindre? I våre samtaler etterpå fant vi at vi hadde overvurdert hans ferdigheter. $\mathrm{Vi}$ hadde ikke tatt hans fortsatte sårbarhet, kanskje spesielt sterk etter "nederlaget" etter to år, alvorlig nok. $0 \mathrm{~g}$ vi forsto ikke godt nok at Kjell nå antakelig forventet av seg selv å være ferdigbehandlet, "frisk", enda vi så for oss kontakt i lang tid fremover.

\section{Avslutning}

$\checkmark$ år erfaring er at selvmord ofte skjer i forbindelse med bedring hos pasientene våre og avslutning av behandlingsprosesser. Jeg har argumentert for at avslutning av behandlingsprosesser kan forstås i lys av de forannevnte grunnvilkărene i tilværelsen. Relasjonenes sårbarh et vises tydelig i det at tidligere vanskeligheter i avslutninger, og destruktive og selvdestruktive mønstre gjentas. $V$ år avhengighet av andre, skam og frykt for å vise svakhet, tydeliggjøres.

A ltfor ofte motarbeides gode avslutninger av behandlingskulturens benektelse av problemet, og av systemforhold bestemt av budsjetter, målstyring, profesjons- eller karrierehensyn osv. Institusjoner som kanskje av beboerne oppleves som deres første virkelige hjem, skaltes og valtes med, bevilgninger tas bort eller reduseres, personalet skifter for ofte. I psykisk helsevern fremmer ofte spesialistordningene kortvarige ansettel sesforhold, erfarne medarbeidere går over i "egen" virksomhet, og det legges altfor lite til rette for at pasienter kan bli med behandleren til nytt arbeidssted. A Itfor ofte er svaret, når pasienten kanskje ønsker kontakt etter avslutning: "N ei, han er nok sluttet her". Vedvarende avhengighet til en behandler anses altfor ofte å være uttrykk for mangel på profesjonalitet hos behandler, eller noe sykelig enten hos pasienten eller i relasjonen. Det settes inn tiltak som at man avslutter for tidlig, eller gjør en endring som blir for vanskelig for pasienten. M er oppmerksomhet rundt disse forholdene kan kanskje forebygge noen av de vonde dødsfallene.
ROP - Tøyen

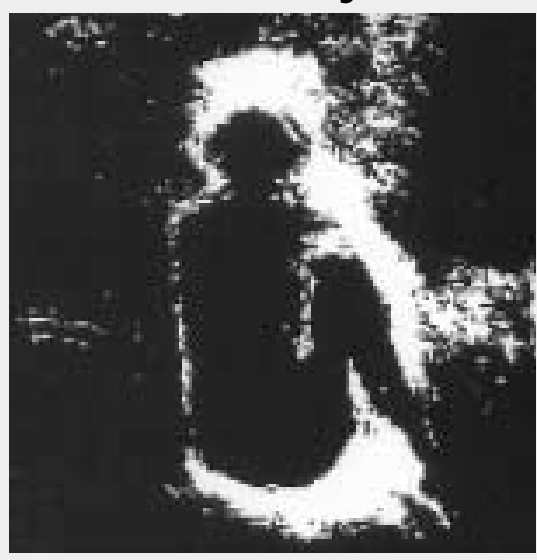

Prosjekt Rus og Psykisk lidelse

- Vi er et oppsøkende behandlingsteam med base på T øyen

- Vi er et prosjekt for deg som:

- har gjort flere alvorlige forsøk på endring i ordinære behandlingstiltak - har behov for å bli oppsøkt der du er ønsker en forandring i din livssituasjon.

- Vi er:

psykologer, sykepleiere, sosionomer og en lege

erfarne fagfolk innen rus og psykisk helsevern

- tålmodige, har god tid, og prøver å møte deg når du trenger oss.

- H os oss kan du få:

- forståelse for ditt problem

aksept for at du er den du er

oppfølging gjennom to år samtaler, praktisk støtte og hjelp.

\section{- Vi ønsker at vi sammen kan:}

- tenke muligheter heller enn hindringer styrke håpet og motvirke håpløshet vise hverandre respekt og unngå vold eller trusler om vold arbeide for en tilværelse der det er mulig å mestre livets vanskeligheter uten å måtte frykte å bli stående alene.

\section{Prosjekt $R$ us og Psykisk lidelse}

$\mathrm{H}$ agegt. 32, 06530 slo

TIf: 24074600

E-post: rpl-toyen@i.Ids.no

Lovisenberg Diakonale Sykehus

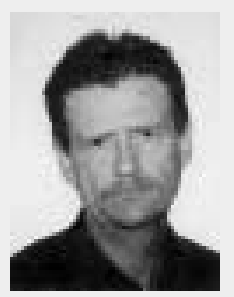

Petter Lohne er

psykolog ved

Prosjekt Rus og

Psykisk Lidelse, (ROP-TØYEN ,

O slo) 